\title{
Kinetics and Mechanism leading to Dimeric Redox Products of 4-Nitrosobenzaldehyde in Alkaline Dioxane-Water Media
}

\author{
Y. Riad, Adel N. Asaad, G.-A. S. Gohar, and A. A. Abdallah \\ Department of Chemistry, Faculty of Science, Alexandria University, Moharram Bey, \\ Alexandria, Egypt
}

Z. Naturforsch. 39 a, $893-898$ (1984); received June 1, 1984

Dedicated to Prof. Dr. Y. Iskander on the occasion of his 70 th birthday

A Cannizzaro disproportionation reaction of 4-nitrosobenzaldehyde (I) and sodium hydroxide in dioxane-water media is kinetically studies by UV-Vis. absorption spectroscopy. The reaction did not give the expected products, namely 4-nitrosobenzyl alcohol and 4-nitrosobenzoic acid, but gave equimolecular quantities of 4,4'-diformylazoxybenzene (II) and 4,4'-dicarboxyazoxybenzene (III) and was found to exhibit third-order kinetics, second-order in aldehyde and firstorder in base. The rate constants as well as the activation thermodynamic parameters were calculated for different temperatures and different dioxane-water compositions, and discussed on the bases of dielectric constant, viscosity and heat of mixing of the medium components. The rate determining step is a hydride ion transfer from the adduct (formed from the attack of one hydroxide ion on molecule of I) to another molecule of I. A mechanism is given to explain the formation of the end reaction products.

\section{Introduction}

The change of nitroaromatics into azoxy- and azobenzene structures has been known for many decades [1-5]. 4-Nitrophenylacetic acid reacts in aqueous methanolic alkali to give a mixture of dioxalo-azo and -azoxybenzenes [6] while the action of aqueous alkali on 4-nitrobenzyl-pyridinium salts [7] or -thioacids [8] gives 4,4'-diformylazoxybenzene (II). The reported mechanisms were only schematic speculations that lead to the end products. $4-\mathrm{Ni}$ trosobenzaldehyde (I) was expected to be a precursor for II [8]. Therefore, in the present work the reaction of sodium hydroxide with I in dioxanewater media was studied in order to see whether the expected products out of the Cannizzaro reaction, namely 4-nitrosobenzyl alcohol and 4-nitrosobenzoic acid, could change in the reaction medium to give the final reaction products. In fact sodium hydroxide reacts with $\alpha$-(4-nitrobenzylthio)acetic acid to give 4,4'-diformylazoxybenzene (II), 4,4'-dicarboxyazoxybenzene and a nitrone acid [9].

\section{Experimental}

\section{Materials}

4-Nitrosobenzaldehyde was prepared by a modification of the method described by Alway [10]: $4.0 \mathrm{~g}(0.026 \mathrm{M})$ of 4-nitrobenzaldehyde in $50 \mathrm{ml}$ methanol and $6.0 \mathrm{ml}$ glacial acetic acid was treated with $4.0 \mathrm{~g}$ zinc dust, in portions, with stirring at $60{ }^{\circ} \mathrm{C}$. The produced yellow-orange solution was oxidised by heating with $50 \mathrm{ml}$ of $10 \%$ potassium dichromate solution and $50 \mathrm{ml}$ of $10 \%$ sulfuric acid for $20 \mathrm{~min}$. The solution was diluted with water, and the precipitated solid was steam distilled, which gave 4-nitrosobenzaldehyde ( $3.1 \mathrm{~g})$ which after three crystallisations from acetone gave a product with melting point $139-140^{\circ} \mathrm{C}$ ([10] m.p. 137.5), IR ( $\mathrm{KBr}$ disk): $1700(\mathrm{C}=\mathrm{O}), 1600 \mathrm{~cm}^{-1}(\mathrm{~N}=\mathrm{O}) ; \mathrm{UV}\left(\mathrm{CH}_{3} \mathrm{OH}\right)$ : $\lambda_{\max }=290 \mathrm{~nm} \log \varepsilon=3.996 ;{ }^{1} \mathrm{H}-\mathrm{NMR}\left(\mathrm{CDCl}_{3}\right): \delta=$ 8.2-8.4 (m, 4H, aromatic), 10.98 (s, H, CHO).

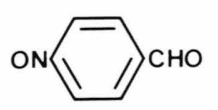

I
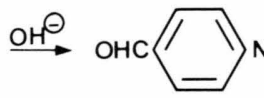

II

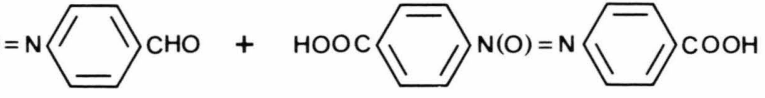

III

Reprint requests to Herrn Y. Riad, Department of Chemistry, Faculty of Science, Alexandria University, Moharram Bey, Alexandria/Ägypten.

0340-4811/ $84 / 0900-0893 \$ 01.30 / 0$. - Please order a reprint rather than making your own copy. 


\section{Treatment of 4-Nitrosobenzaldehyde with Sodium Hydroxide}

$25 \mathrm{ml}$ of $0.01 \mathrm{M}$ of 4-nitrosobenzaldehyde were added to $25 \mathrm{ml} 0.4 \mathrm{~N}$ sodium hydroxide solution. The mixture was heated to $60{ }^{\circ} \mathrm{C}$ for $5 \mathrm{~min}$. Cold water was added and the precipitated solid was dried and crystallised from dry benzene in yellow needles m.p. $193{ }^{\circ} \mathrm{C}$ alone or mixed with an authentic specimen of 4,4'-diformylazoxybenzene ([11] m.p. 193-194 ${ }^{\circ} \mathrm{C}$ ). (Found: C, 65.9; H, 3.9; N, 11.07 . Calc. for $\mathrm{C}_{14} \mathrm{H}_{10} \mathrm{~N}_{2} \mathrm{O}_{3}$ : C, 66.1; $\mathrm{H}, 3.9 ; \mathrm{N}, 11.02 \%$ ). IR $(\mathrm{KBr}$ disk $): 1700 \quad(\mathrm{C}=\mathrm{O}), 1425(\mathrm{~N}=\mathrm{N})$ and $1295 \mathrm{~cm}^{-1} \quad(\mathrm{~N}-\mathrm{O}) ; \mathrm{UV}$ (dioxane) $\lambda_{\max }=332 \mathrm{~nm}$ $\log \varepsilon=4.44 ;{ }^{1} \mathrm{H}-\mathrm{NMR}\left(\mathrm{d}^{6}\right.$-DMSO): $\delta=8.12-8.4(\mathrm{~m}$, $8 \mathrm{H}$, aromatic), $10.1-10.2(\mathrm{~d}, 2 \mathrm{H}, \mathrm{CHO})$. Acidification of the alkaline filtrate with dilute sulfuric acid gave a yellow acid which was crystallised from acetic acid, m.p. $>360^{\circ} \mathrm{C}$. It was identified as $4,4^{\prime}$ dicarboxyazoxybenzene $[6,12]$.

Symmetrical 1,4-dixoane was purified as described in the literature $[13,14]$. The water used in the preparation of solutions and in the kinetic runs was freshly distilled from alkaline potassium permanganate.

\section{Kinetic Procedure}

The reaction was followed by measuring the ultraviolet-visible absorption at $380 \mathrm{~nm}$ using a Unicam $1805 \mathrm{SP}$ spectrophotometer coupled with an ultrathermostate. One $\mathrm{ml}$ of each of the reactant solutions, 4-nitrosobenzaldehyde $\left(2 \times 10^{-3} \mathrm{~mol} \mathrm{l}^{-1}\right.$ in appropriate dioxane-water mixture) and sodium hydroxide $\left(4 \times 10^{-3} \mathrm{~mole}^{-1}\right.$ in water $)$ were separately introduced into the two parts of the two compartment cell (Hellma, 238-QS) and thermostated for $15 \mathrm{~min}$. After shaking the cell contents, $5-10 \mathrm{sec}$, the absorption of the mixture was recorded at suitable time intervals.

The amount, $x$, of reacted 4-nitrosobenzaldehyde was calculated by applying the equation

$$
x=\frac{A-l a \varepsilon_{1}}{l\left[0.5\left(\varepsilon_{2}+\varepsilon_{3}\right)-\varepsilon_{1}\right]},
$$

where $A$ is the absorption of the mixture, $l$ is the cell thickness $(0.437 \mathrm{~cm}), a$ is the initial concentration of 4-nitrosobenzaldehyde, which was always taken as $1 \times 10^{-3} \mathrm{~mole} \mathrm{l}^{-1}, \varepsilon_{1}=549, \varepsilon_{2}=5143$ and $\varepsilon_{3}=5200$ $1 \mathrm{~mole}^{-1} \mathrm{~cm}^{-1}$ are the molar extinction coefficients of 4-nitrosobenzaldehyde (I), 4,4'-diformylazoxybenzene (II) and 4,4'-dicarboxyazoxybenzene (III) respectively.

\section{Results and Calculations}

The third order rate constant $\boldsymbol{k}_{3}\left(1^{2} \mathrm{~mole}^{-2} \mathrm{sec}^{-1}\right)$ was calculated from the equation $[15,16]$

$$
\boldsymbol{k}_{3}=\frac{1}{a t(a-b)} \cdot \frac{x}{a-x}+\frac{1}{t(a-b)^{2}} \ln \frac{b(a-x)}{a(a-x)},
$$

where $x$ is the concentration of the reacted 4-nitrosobenzaldehyde at time $t$, and $a$ and $b$ are the initial concentrations of 4-nitrosobenzaldehyde and sodium hydroxide, respectively. The reaction was followed to not less than $85 \%$ completion in various dioxane-water mixtures, $20-50 \%(\mathrm{w} / \mathrm{w})$, at 35,45 , 55 and $65^{\circ} \mathrm{C}$.

Data for a typical run are given in Table 1, and the values of $\boldsymbol{k}_{3}$ are collected in Table 2 for the indicated temperatures. A statistical least squares

Table 1. Kinetics of reaction of $1 \times 10^{-3} \mathrm{M} \mathrm{I}$ with $2 \times 10^{-3} \mathrm{M}$ sodium hydroxide in $50.68 \%(\mathrm{w} / \mathrm{w})$ dioxane-water at $35^{\circ} \mathrm{C}$.

\begin{tabular}{rll}
\hline $\begin{array}{l}\text { Time } \\
{[\mathrm{sec}]}\end{array}$ & $\begin{array}{l}\text { Absorbance } \\
\text { at } \lambda=380 \mathrm{~nm}\end{array}$ & $\begin{array}{l}\boldsymbol{k}_{3} \\
{\left[1^{2} \mathrm{~mol}^{-2} \mathrm{sec}^{-1}\right]}\end{array}$ \\
\hline 530 & 0.74 & 108.92 \\
740 & 0.82 & 99.06 \\
955 & 0.96 & 109.35 \\
1185 & 1.08 & 114.78 \\
1420 & 1.17 & 115.00 \\
1660 & 1.24 & 112.73 \\
1965 & 1.32 & 110.77 \\
\hline
\end{tabular}

mean $=110.09 \pm 5$

Table 2. Third-order rate constants and activation energies

\begin{tabular}{|c|c|c|c|c|c|}
\hline \multirow{2}{*}{$\begin{array}{l}\text { Dioxane } \\
{[\mathrm{w} t \%]}\end{array}$} & \multicolumn{4}{|c|}{$\boldsymbol{k}_{3}\left[1^{2} \mathrm{~mol}^{-2} \mathrm{sec}^{-1}\right]$} & \multirow{2}{*}{$\begin{array}{l}\boldsymbol{E} \\
{\left[\mathrm{kJ} \mathrm{mol}^{-1}\right]}\end{array}$} \\
\hline & $35^{\circ} \mathrm{C}$ & $45^{\circ} \mathrm{C}$ & $55^{\circ} \mathrm{C}$ & $65^{\circ} \mathrm{C}$ & \\
\hline 50.68 & $\begin{array}{l}110.1 \\
\pm 5\end{array}$ & $\begin{array}{l}171.2 \\
\pm 6\end{array}$ & $\begin{array}{l}298.4 \\
\pm 13\end{array}$ & $\begin{array}{l}443.4 \\
\pm 18\end{array}$ & $\begin{array}{r}41.02 \\
\pm 0.01\end{array}$ \\
\hline 41.35 & $\begin{aligned} & 451.7 \\
\pm & 35\end{aligned}$ & $\begin{array}{c}533.1 \\
\pm 18\end{array}$ & $\begin{array}{l}811.0 \\
\pm 15\end{array}$ & $\begin{array}{l}1519.0 \\
\pm 11\end{array}$ & $\begin{array}{r}28.73 \\
\pm 0.87\end{array}$ \\
\hline 30.01 & $\begin{array}{l}471.6 \\
\pm 23\end{array}$ & $\begin{array}{l}708.7 \\
\pm 20\end{array}$ & $\begin{array}{l}767.9 \\
\pm 11\end{array}$ & $\begin{array}{l}1522.8 \\
\pm 17\end{array}$ & $\begin{array}{r}24.26 \\
\pm 0.99\end{array}$ \\
\hline 20.67 & $\begin{aligned} & 164.6 \\
\pm & 13\end{aligned}$ & $\begin{array}{l}256.9 \\
\pm 4\end{array}$ & $\begin{array}{c}493.0 \\
\pm 17\end{array}$ & $\begin{array}{l}712.9 \\
\pm 3\end{array}$ & $\begin{array}{r}36.93 \\
\pm 1.11\end{array}$ \\
\hline
\end{tabular}
of the Cannizzaro reaction. 
Table 3. Activation thermodynamic parameters.

\begin{tabular}{|c|c|c|c|c|c|}
\hline \multirow[t]{2}{*}{$t\left[{ }^{\circ} \mathrm{C}\right]$} & \multirow[t]{2}{*}{ Parameters } & \multicolumn{4}{|c|}{ Dioxane [wt\%] } \\
\hline & & 50.68 & 41.35 & 30.01 & 20.67 \\
\hline 35 & $\begin{aligned} & \boldsymbol{\Delta} \boldsymbol{G}^{\neq} \mathrm{kJ} \mathrm{mol}^{-1} \\
& \boldsymbol{\Delta} \boldsymbol{H}^{\neq} \mathrm{kJ} \mathrm{mol}^{-1} \\
&-\boldsymbol{\Delta} \boldsymbol{S}^{\neq} \mathrm{J} \mathrm{mol}^{-1} \mathrm{deg}^{-1}\end{aligned}$ & $\begin{array}{l}63.68 \\
38.45 \\
81.39\end{array}$ & $\begin{array}{r}85.98 \\
26.18 \\
194.17\end{array}$ & $\begin{array}{r}81.44 \\
21.70 \\
193.96\end{array}$ & $\begin{array}{r}96.59 \\
34.37 \\
202.67\end{array}$ \\
\hline 45 & $\begin{array}{c}\Delta \boldsymbol{G}^{\neq} \mathrm{kJ} \mathrm{mol}^{-1} \\
\boldsymbol{\Delta} \boldsymbol{H}^{\neq} \mathrm{kJ} \mathrm{mol}^{-1} \\
-\boldsymbol{\Delta} \boldsymbol{S}^{\neq} \mathrm{J} \mathrm{mol}^{-1} \mathrm{deg}^{-1}\end{array}$ & $\begin{array}{l}64.50 \\
38.37 \\
82.12\end{array}$ & $\begin{array}{r}87.53 \\
26.10 \\
193.18\end{array}$ & $\begin{array}{r}60.77 \\
21.62 \\
122.93\end{array}$ & $\begin{array}{r}97.64 \\
34.28 \\
199.24\end{array}$ \\
\hline 55 & $\begin{array}{c}\boldsymbol{\Delta} \boldsymbol{G}^{\neq} \mathrm{kJ} \mathrm{mol}^{-1} \\
\boldsymbol{\Delta} \boldsymbol{H}^{\neq} \mathrm{kJ} \mathrm{mol}^{-1} \\
-\boldsymbol{\Delta} \boldsymbol{S}^{\neq} \mathrm{J} \mathrm{mol}^{-1} \mathrm{deg}^{-1}\end{array}$ & $\begin{array}{l}65.29 \\
38.29 \\
81.68\end{array}$ & $\begin{array}{r}88.32 \\
26.02 \\
189.96\end{array}$ & $\begin{array}{r}84.07 \\
21.53 \\
190.44\end{array}$ & $\begin{array}{r}97.86 \\
34.20 \\
194.08\end{array}$ \\
\hline 65 & $\begin{array}{c}\Delta \boldsymbol{G}^{\mp} \mathrm{kJ} \mathrm{mol}^{-1} \\
\boldsymbol{\Delta} \boldsymbol{H}^{\neq} \mathrm{kJ} \mathrm{mol}^{-1} \\
-\Delta \boldsymbol{S}^{\mp} \mathrm{J} \mathrm{mol}^{-1} \mathrm{deg}^{-1}\end{array}$ & $\begin{array}{l}66.05 \\
38.20 \\
82.34\end{array}$ & $\begin{array}{r}84.46 \\
25.93 \\
185.00\end{array}$ & $\begin{array}{r}83.98 \\
21.45 \\
184.99\end{array}$ & $\begin{array}{r}98.77 \\
34.12 \\
191.27\end{array}$ \\
\hline
\end{tabular}

treatment [17] of the Arrhenius equation was used to calculate the activation energies $\boldsymbol{E}$ (cf. Table 2). The correlation coefficient values $(r)$ of the linear plot of the Arrhenius equation are almost equal to unity.

The entropies, enthalpies and free energies of activation $\Delta \boldsymbol{S}^{\ddagger}, \Delta \boldsymbol{H}^{\ddagger}$ and $\Delta \boldsymbol{G}^{\neq}$, respectively were calculated from the expressions

$$
\begin{aligned}
& \log \boldsymbol{k}_{3} / \boldsymbol{T}=10.3187+\frac{\Delta \boldsymbol{S}^{\neq}}{19.147}-\frac{\Delta \boldsymbol{H}^{\neq}}{19.147 \boldsymbol{T}}, \\
& \boldsymbol{\Delta} \boldsymbol{G}^{\neq}=\boldsymbol{\Delta} \boldsymbol{H}^{\neq}-\boldsymbol{T} \boldsymbol{\Delta} \boldsymbol{S}^{\neq},
\end{aligned}
$$

where $\Delta \boldsymbol{H}^{\neq}, \Delta \boldsymbol{S}^{\neq}$and $\boldsymbol{k}_{3}$ are in $\mathrm{J}_{\mathrm{mole}}^{-1}, \mathrm{~J} \mathrm{~mole}^{-1}$ $\mathrm{deg}^{-1}$ and $\mathrm{l}^{2} \mathrm{~mole}^{-2} \mathrm{sec}^{-1}$, respectively. The activation thermodynamic parameters are collected in Table 3.

\section{Discussion}

The reaction between 4-nitrosobenzaldehyde and sodium hydroxide in dioxane-water media is a clear kinetic reaction. The absorption vs. time curves of the reaction runs are identical to that for artificial standard solutions of reactants and products (having the same concentration as the original kinetic run), indicating that the intermediates have no absorption to overlap with the reactants and products absorptions (Figure 1).

In order to get a full picture of the mechanism of such a dimeric redox system, the kinetics were studied in different media containing varying dioxane-water percentages. The reaction was found to obey a third-order rate law, second-order in 4-ni-

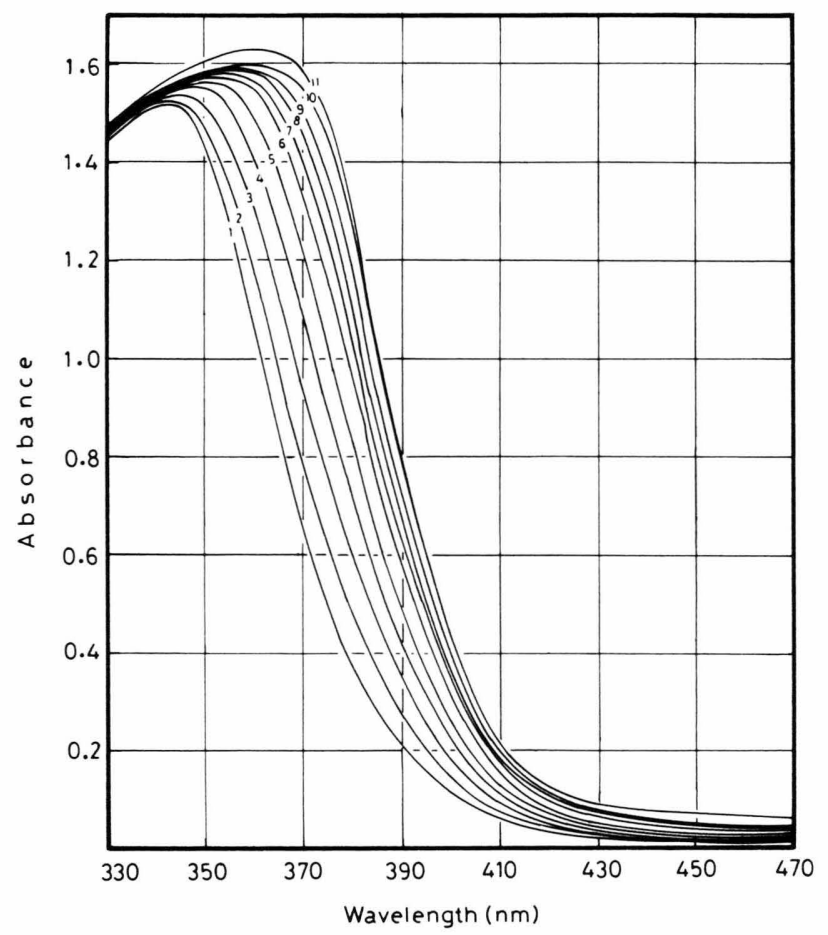

Fig. 1. The absorption spectra at different time intervals of the reaction studied in $50.68 \%(\mathrm{w} / \mathrm{w})$ dioxane-water at $35^{\circ} \mathrm{C}$.

trosobenzaldehyde and first-order in sodium hydroxide.

The transition state is formed form the approach of the adduct (formed form the attack of one hydroxide ion on to the carbonyl carbon of one molecule of aldehyde (I)) to another molecule of (I). The rate determining step is the hydride ion transfer 


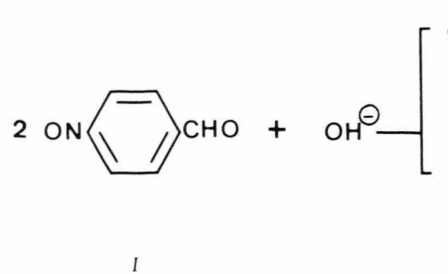<smiles>CC(C)CC(C)CC(=O)c1ccc(O)cc1</smiles>

IV

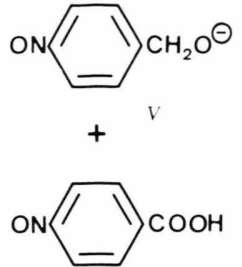

$\checkmark I$ from the adduct to the other molecule of (I) thus leading to 4-nitrosobenzylalcoholate and 4-nitrosobenzoic acid. That is, the rate determining step is the autoredox Cannizzaro reaction.

The third order rate constant values $\boldsymbol{k}_{3}$, Table 2 , show a remarkable variation with solvent composition. In general, these values increase with rising the water content of the reaction medium, and a maximum was observed near $30 \%$ dioxane-water.

The increase of the rate constant with increasing dielectric constant of the reaction medium (Fig. 2) indicates that the transition state (IV) is more polar than the reactants. The carbonyl groups of both aldehyde molecules in (IV) are likely to be polarised by hydrogen bonding to water molecules [20], this increases the reaction rate with increasing the water content of the reaction medium.

The values of the dielectric constant are taken or interpolated from the data of Åkerlof [21] for different solvent mixtures.

Application of the electrostatic theories, either ion-molecular dipole interaction [22, 23] by plotting $\log \boldsymbol{k}_{3}$ against 1/D, or molecular dipole-molecular dipole interaction $[24,25]$ by plotting $\log \boldsymbol{k}_{3}$ against $(\boldsymbol{D}-1) /(2 \boldsymbol{D}+1)$, gave poor linearity in the low range of the dielectric constant for all the applied temperatures. Similar behaviour had been attributed to solvent sorting or preferential solvation of the activated complex by water $[26,27]$. The observation of a maximum in rate constant near 30\% dioxane-water $(w / w)$ was undoubtly due to the participation of other factors besides the dielectric constant. The hydride ion transfer in the transition state (IV) is an intermolecular process, therefore the increase of the viscosity of the reaction medium should enhance the reaction rate. The viscosity of dioxane-water mixtures has a maximum near 30\% $(\mathrm{w} / \mathrm{w})$, Table 4 , which has been attributed to structure promotion $[28,29]$.

The mixing of dioxane and water is endothermic at high molar concentrations of dioxane but exothermic at low dixoane concentration $[30,31]$. This indicates that the mutual attraction between water and dioxane is much weaker at lower dioxane content, and that the water molecules are more readly available for solvation than in case of higher dioxane content. Thus the transition state will be more solvated at low dioxane content and hence less energetic.

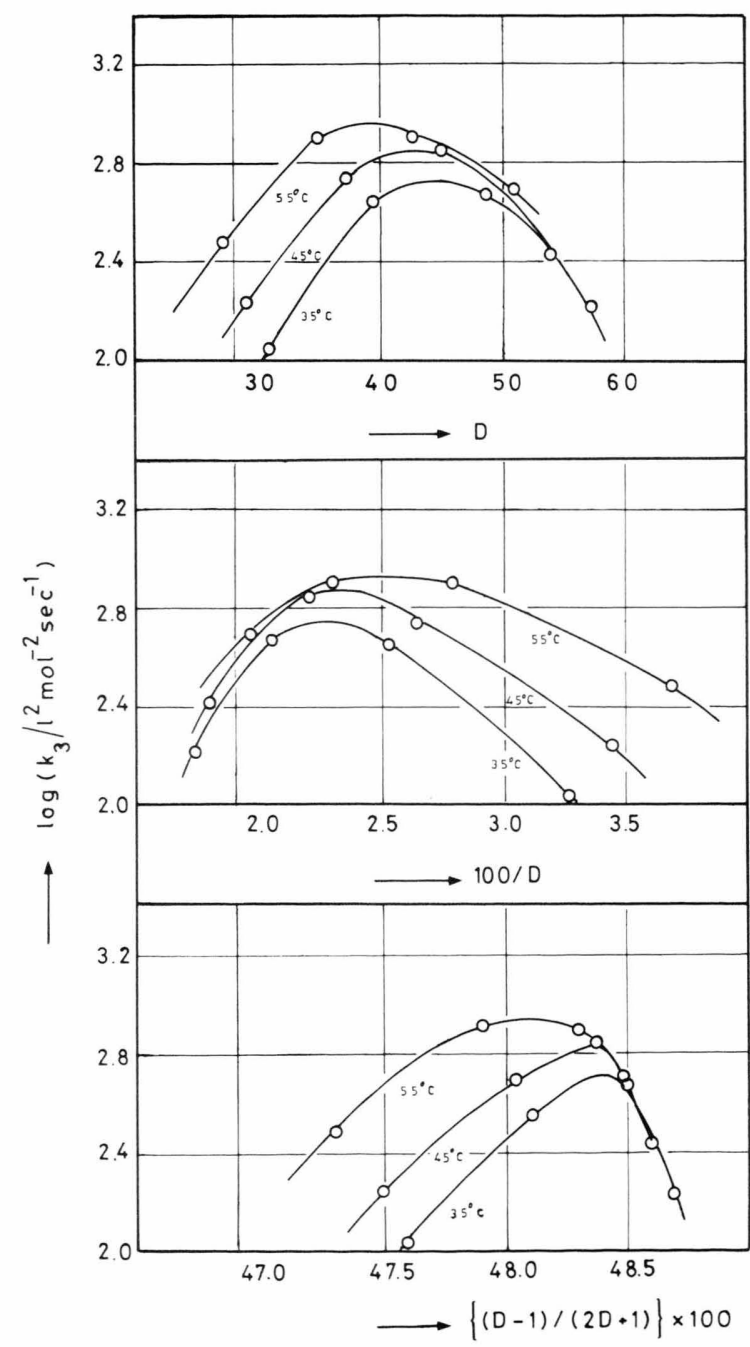

Fig. 2. Plots of the rate of the reaction against the dielectric constant of the medium. 
Table 4. Heat of mixing $\left(\boldsymbol{\Delta} \boldsymbol{H}_{\mathrm{m}}\right.$ in $\left.\mathbf{J} \mathrm{mol}^{-1}\right)$ and viscosity ( $\boldsymbol{\eta}$ in c. P, ) of dioxane-water mixture at $25^{\circ} \mathrm{C}$.

\begin{tabular}{lrrrrrrr}
\hline $\begin{array}{l}\text { Dioxane } \\
{[\mathrm{mol} \%]}\end{array}$ & 10 & 20 & 30 & 40 & 50 & 60 & 70 \\
\hline $\boldsymbol{\Delta} \boldsymbol{H}_{\mathrm{m}}$ & -523.0 & -543.9 & -351.5 & -117.1 & +83.7 & +292.9 & 435.1 \\
$\boldsymbol{\eta}$ & 1.59 & 1.90 & 2.00 & 1.83 & 1.60 & 1.42 & 1.38 \\
\hline
\end{tabular}

The activation energies for different dioxanewater mixtures (cf. Table 2) lie in the range characteristic for the Cannizzaro reaction [32, 33]. The energy of activation shows a minimum at nearly $30 \%$ dioxane-water, which is also due to the solvation of the transition state (IV) and to the maximum viscosity at this solvent composition.

The thermodynamic parameters, free energies $\Delta \boldsymbol{G}^{\ddagger}$, enthalpies $\Delta \boldsymbol{H}^{\ddagger}$ and entropies $\Delta \boldsymbol{S}^{\ddagger}$ of activation are collected in Table 3 . In general, $\boldsymbol{\Delta} \boldsymbol{G}^{\neq}$ increases as water is added and $\boldsymbol{\Delta} \boldsymbol{H}^{\neq}$shows a minimum near $30 \%$ dioxane-water mixture. The entropy of activation $\Delta \boldsymbol{S}^{\neq}$has a large negative value characteristic for hydride ion transfer and decreases regularly as the transition state is organised by solvation, that is at high water concentrations.

In order to give a full picture for the mechanism of such a reaction we have concentrated mainly on three steps; (i) the transformation of 4-nitrosobenzaldehyde, via Cannizzaro reaction, to 4-nitrosobenzylalcohol and 4-nitrsosbenzoic acid, (ii) the transformation of 4-nitrosobenzylalcohol to 4,4'diformylazoxybenzene and (iii) the transformation of 4-nitrosobenzoic acid to 4,4'-dicarboxyazoxybenzene.

The kinetic data, rate constants $\left(\boldsymbol{k}_{3}\right)$ and the activation thermodynamic parameters show that the rate determining step is the hydride ion transfer in the transition state (IV). This step leads to the formation of 4-nitrosobenzylalcohol and 4-nitrosobenzoic acid.

It is worth mentioning here that radical chain mechanisms have been proposed for the Cannizzaro reaction [ 34 35] but were excluded because radical initiators, benzoyl or sodium peroxide, or inhibitors, hydroquinone or diphenylamine, have no effect on the rate [36]. Swain et al. [20] recently reported that when the reaction was carried out in deuterium oxide, the alcohol produced from the Cannizzaro reaction of benzaldehyde or formaldehyde contains no carbon-bound deuterium; this excludes all mechanisms involving a hydride ion transfer from or to oxygen atoms.

The formation of azoxy compounds from aromatic nitroso compounds and aryl hydroxylamines, the so called azoxy coupling reaction, proceeds by way of a symmetrical intermediate with chemically equivalent nitrogen atoms [37-40], which has a structure of bis-anion (VII) in akaline medium.<smiles>[O-]N([O-])N([Ga])[Ga]</smiles>

The formed 4-nitrosobenzylalcohol, via Cannizzaro reaction, changes in the alkaline medium into 4-hydroxylaminobenzaldehyde, which reacts either with 4-nitrosobenzaldehyde or dimerises [41] giving $4,4^{\prime}$-diformylazoxybenzene as represented in the following scheme:

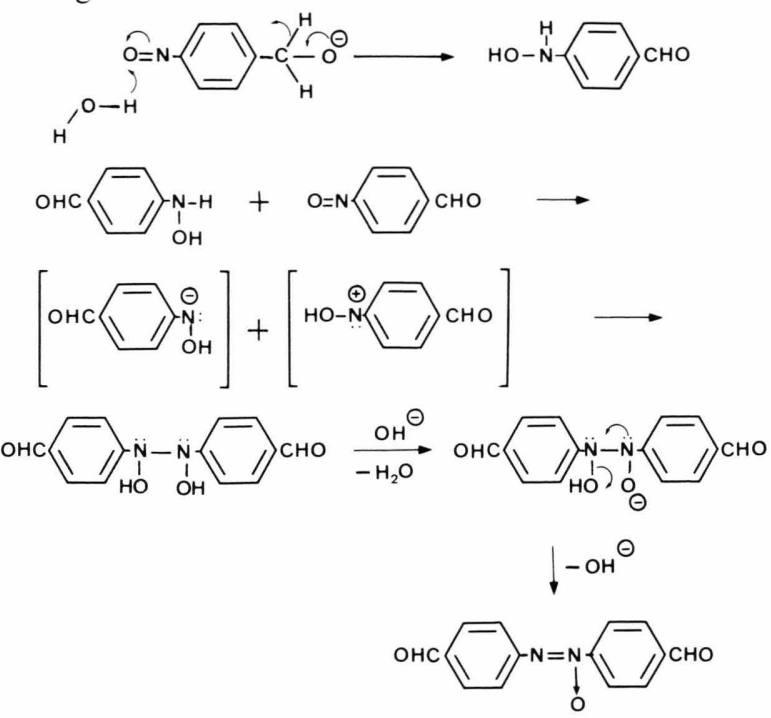

4-Nitrosobenzoic acid changes rapidly in the presence of alkali into 4,4'-dicarboxyazoxybenzene [42]. 
[1] P. Buck, Angew. Chem. Int. Ed. Engl. 8, 120 (1969).

[2] H. Zollinger, Azo and Diazo-Chemistry, Ch. 9, Interscience, New York 1961.

[3] W. H. Perkin Transact. 37, 546 (1880).

[4] O. Fischer and E. Hepp, Berichte 26, 223 (1893)

[5] A. G. Green, A. H. Davies, and R. S. Horsfall, J. Chem. Soc. 1907, 2078.

[6] V. M. Clark, J. B. Hobbs, and D. W. Hutchinson, Tetrahedron 25, 4241 (1969).

[7] E. H. Huntress and G. L. Foote, J. Amer. Chem. Soc. 64, 1017 (1942).

[8] Y. Iskander and Y. Riad, J. Chem. Soc. 1951, 2054

[9] Unpublished results by Y. Riad, A. N. Asaad, G.-A. S. Gohar, and A. A. Abdallah

[10] F. J. Alway, Berichte 36, 2303 (1903).

[11] S. B. Hanna, Chem. Comm. 1965, 487.

[12] E. B. Reid and E. G. Pritchett, J. Org. Chem. 18, 715 (1953).

[13] Collective Authers, Organikum, VEB Deutscher Verlag der Wissenschaften, 15th edition Berlin 1977.

[14] K. Hess and H. Frahn, Berichte 17, 2633 (1938).

[15] G. Aksens and D. Aksens, Acta. Chem. Scand. 18, 1623 (1964).

[16] H. Mauser, Formale Kinetik, Bertelsmann Universitätsverlag 1974.

[17] E. S. Swinbourne, Analysis of Kinetic Data, Thomas Nelson and Sons. Ltd., London 1971.

[18] S. Glasstone, K. J. Laidler, and H. Eyring, The Theory of Rate Processes, McGraw-Hill, New York 1941

[19] A. N. Asaad and F. Y. Khalil, Z. Naturforsch. 39 a, 95 (1984).

[20] C. G. Swain, A. L. Powell, W. A. Sheppard, and C. R. Morgan, J. Amer. Chem. Soc. 101, 3576 (1979).

[21] G. Åkerlof, J. Amer. Chem. Soc. 54, 4125 (1932).

[22] K. J. Laidler and G. A. Landskroener, Trans. Faraday Soc. 52, 200 (1956).
[23] K. Hiromi, Bull. Chem. Soc. Japan 33, 1251 (1960).

[24] K. J. Laidler and H. Eyring, Ann. N.Y. Acad. Sci. 39, 303 (1940).

[25] E. S. Amis and J. F. Hinton, Solvent Effect on Chemical Phenomena, Academic Press, New York 1973; E. S. Amis, Solvent Effect on Reaction Rates and Mechanisms, Academic Press, New York 1966.

[26] A. H. Fausberg and S. Winstein, J. Amer. Chem. Soc. 28, 2770 (1956)

[27] E. Tommila and T. Vihavainen, Acta Chem. Scand. 22, 3224 (1968); E. Tommila and A. Hella, Ann. Acad. Sci. Fenn. Ser. A II, 53, 1 (1954).

[28] A. M. Hafez and H. Sadek, Acta Chim. Acad. Scien. Hungaricoe, Tomus 89 (3), 257 (1976).

[29] R. L. Broadwater, Electrochim. Acta 16, 667 (1971)

[30] Landolt-Börnstein, Physikalisch-Chemische Tabellen, Erg. I, 852 (1927)

[31] A. T. Kister and D. C. Waldman, J. Phys. Chem. 62, 245 (1958)

[32] E. L. Molt, Rec. Trav. Chim. Pays-Bas 56, 233 (1937)

[33] E. Tommila, Ann. Acad. Sci. Fenn. Ser. A 59 (8), 3 (1942); Chem. Abstra. 38, 6175 (1944).

[34] F. Haber and R. Willstätter, Ber. 64, 2851 (1931).

[35] J. Weiss, Trans Faraday Soc. 37, 782 (1941).

[36] K. H. Gieb, Z. Phys. Chem. Abt. A 169, 41 (1934); E. R. Alexander, J. Amer. Chem. Soc. 69, 289 (1937).

[37] M. M. Shemyakin, V. I. Maimind, and B. K Vaichunaite, Dokl. Akad. Nauk SSSR 1260 (1957).

[38] L. A. Neiman, V. I. Maimind, and M. M. Shemyakin, Tetrahedron Letters 35, 3157 (1965).

[39] G. A. Russell and E. J. Geels, J. Amer. Chem. Soc. 87, $122(1965)$

[40] J. March, Advanced Organic Chemistry, 2nd edition, McGraw-Hill New York 1977, p. 581

[41] G. T. Knight and B. Saville, J. Chem. Soc. Perkin Trans. 2, 1973, 1550

[42] G. Heller, Berichte 46, 286 (1913). 